\title{
Evaluation of population parameters and biometric data of an Eurasian Collared Dove (Streptopelia decaocto Friv.) population in the Great Plain of Hungary
}

\author{
Sámuel Varga - Lajos Juhász \\ University of Debrecen Faculty of Agricultural and Food Sciences and Environmental Management, \\ Institute of Animal Science, Biotechnology and Nature Conservation, Debrecen, Hungary \\ varga.samuel@agr.unideb.hu
}

\begin{abstract}
SUMMARY
The Eurasian Collared Dove shows different patterns in density all over Hungary. In some cases, the population has decreased to a lower level, but there are habitats where the population remained stable.

Several factors were taken into consideration during the evaluation of this phenomenon. These publications state that the increased urbanization of corvids, the lack of food sources, and the changes in nesting sites caused the decrease in numbers. During our research, we intend to contrast the differences in population structure of Collared Doves that differ from each other in the density of predators presented at nesting sites. As a first step, in this paper, numerous samples $(n=118)$ were taken from a population that is less influenced by corvid species' nest predation. Our prediction was that the population parameters remained at the level of 1980's, in which the population of Eurasian Collared Dove has reached its maximum, according to further publications.

During the evaluation process, our data were collected from hunting bags near Nyíregyháza. Results were compared with former publications. We stated that the population structure, such as age and gender distribution remained stable in the evaluated population. In addition, morphometric factors of the collected individuals were also measured, such as weight, wing length, $3^{\text {rd }}$ primary feather, and tail length, which were compared with former surveys. During statistical tests no significant difference was revealed among population parameters, but there were significant differences between most of the morphometric data, $(p>0.05)$.
\end{abstract}

Keywords: population structure, morphometry, Collared Dove

\section{INTRODUCTION}

The Eurasian Collared Dove is originally an IndoAfrican species. Its range was set from the Middle East to Rear India, where four subspecies were expanded (Glutz and Bauer 1980, Cramp 1985). The expansive spread began in the early 1920's, the first Hungarian observation set in 1926, in Tiszaug (46.8537215 N, 20.052921 E) (Bankovics 1984), its first nesting was dated in 1932 in Berettyóújfalu (47.2196438 N, 21.5362811 E) (Greschik 1933). From the 1950's - except in closed forests - the Collared Dove became widespread in Hungary (Keve and Kleiner 1944, Keve 1950, 1962). After that several parts of Western-Europe were colonized by this species, it was observed Iceland in 1964. The expansion of the species was extremely intensive in the European parts of the former Soviet Union (Bozsko 1976, Hengeveld in Hagelmeijer and Blair 1997). The reason of this phenomenon still has not been carried out completely: in Algeria the Collared Dove was mainly spread through urban habitats within a few years and expanded to agricultural lands in 2006. This process is still going on nowadays (Bendjoudi et al. 2015). The nesting population of the Eurasian Collared Dove in Hungary was estimated a number of 100 000-300 000 individuals at the end of the $20^{\text {th }}$ century (Magyar et al. 1998). This species typically follows human related habitats, and land covers, while some populations are directly linked to human settlements. However, it also appears as nesting species in farmlands (Juhász 1987). Rural woods and gallery forests can also be function as roost sites, but in the last few years the Collared Dove populations were compressed in villages. In winter, Collared
Doves are gathered in big groups at night seeking shelter in parks and they leave the city to seek food sources (Eraud et al. 2011). In the daytime doves can also be found near animal farms, in order to get food, then these individuals march together to their common roosts (Faragó 2007). The Collared Dove's population has reached its maximum in the 1980's, a decreasing tendency was commonly proceeded. According to one of the previous publications (Juhász 1990) we suggest that the decrease of the Eurasian Collared Dove's population can be tracked to the high pressure on hunting, modern agriculture and storing methods, and last, but not least the increasing density of predators, e.g. Hooded Crows (Corvus cornix L.), and Magpies (Pica pica L.). The competitor species such as Feral Pigeons (Columba livia L.) have been also increased. In our opinion, the greatest source of danger is the increased number of hooded crows in Debrecen (Kövér et al. 2015). The main aim of this study was to collect and summarize data of a Collared Dove population that is the least influenced by these factors. According to previous researches, the population in Nyíregyháza, Hungary fits these conditions. In this paper, our goals were to specify and compare the age and sex distribution of a Eurasian Collared Dove population. Our prediction is that in the population of Nyíregyháza young birds are dominant, with high sexual activity, and the age and sex distribution is identical or better than presented in earlier researches.

\section{MATERIALS AND METHODS}

\section{Sample collection}

Our samples were collected from hunting bags of a hunting association near Nyíregyháza's suburban 
region in September 2016 and 2017. This region has a huge amount of agricultural lands with sunflower fields, giving a stable food source to the Collared Doves. In total, 118 samples were collected and measured based on the EURING protocol. The sex and age of the individuals, so the sexual activity were calculated from samples. In addition, morphometric measurements were also recorded, such as weight, wing length, $3^{\text {rd }}$ quill-feather, and tail length. These records were compared with previous researches, to confirm our predictions that the nesting population's parameters hasn't changed in the last 30 years at the sampling site (Figure 1).

Figure 1: Map of the sampling site

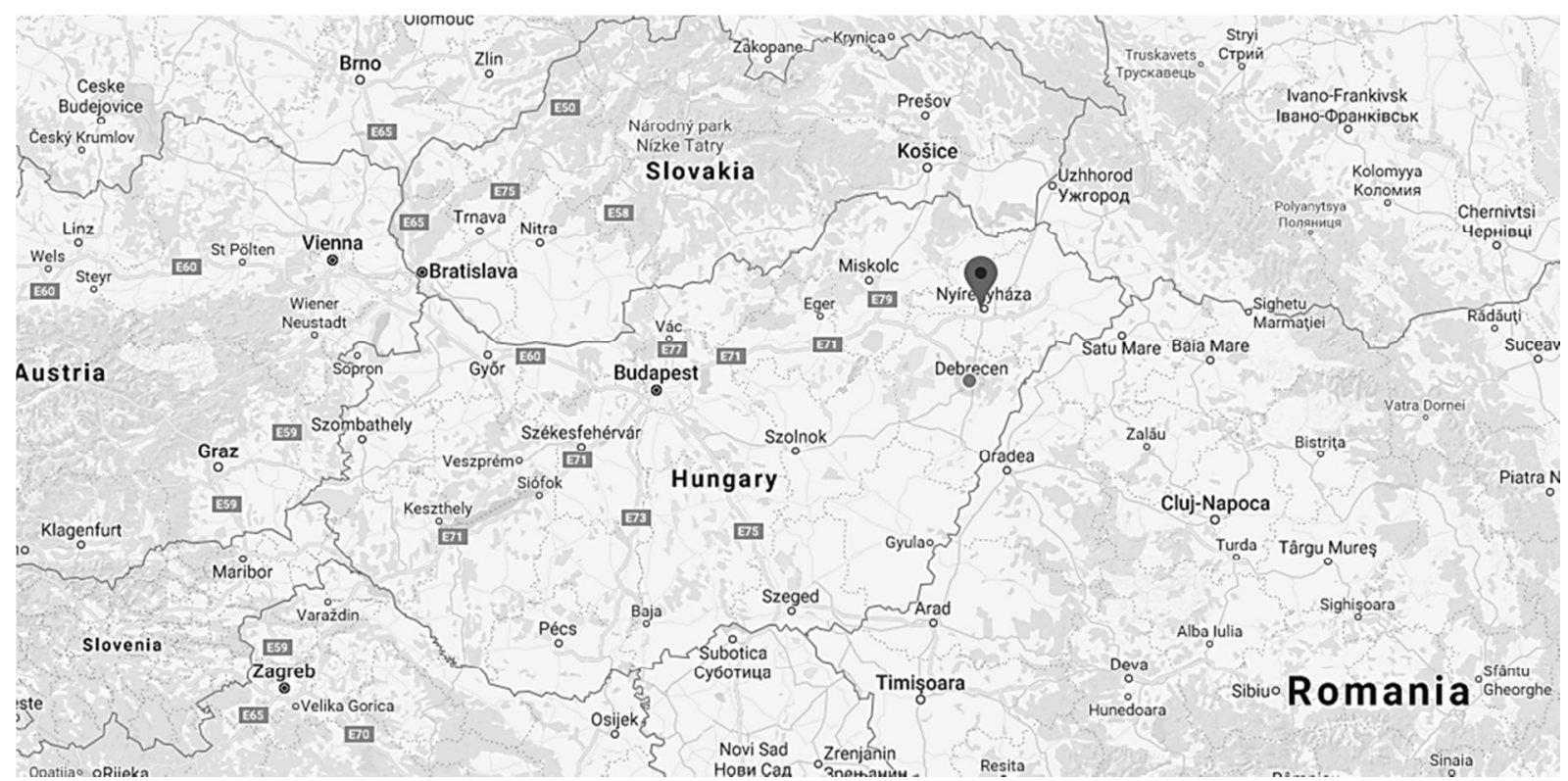

\section{Statistical evaluation}

We Used SPSS 23.0 software to perform statistical testing. One-sample t-test was used to compare the sampled population's morphometric data to former results. Independent samples t-test was used to determine, if there were any difference between males and females within population. Chi-square test was applied to confirm the similarity of age and sex distribution. Chi-square test was also used to test the distributions of sexually active individuals in comparison with the values of the overall population.

\section{RESULTS}

During the research period, 118 Eurasian Collared Doves were examined to gather morphometric data and create sex and age distribution from samples. The sorted data were tested by independent samples t-test to determine differences by sex (Table 1).

The age and sex distribution of the sampled population were calculated (Figure 2) and appeared to be like the same as the data collected in the 1980's. The age distribution showed that $54.2 \%$ of the population was adults. It is $4.5 \%$ higher than the data published by Bozsko in 1983. The sex distribution was nearly the same in the two studies. Bozsko (1983) published a sex distribution of $60 \%$ to males and $40 \%$ to females in the same sampling site and season. In our research these values were 61.9 and $38.1 \%$, in overview. The Chi-square test proved that there is no significant difference between our measurements and the data provided in 1983 (age: $\chi^{2=} 0.847 ; \mathrm{p}=0.357$; sex: $\chi^{2}=1.71 ; p=0.679$ )

Table 1

Descriptive statistics of the investigated Eurasian Collared Dove population (grouped by sex)

\begin{tabular}{llccc}
\hline \multicolumn{1}{c}{ Sex } & $\mathrm{N}$ & Mean & $\begin{array}{c}\text { Standard } \\
\text { deviation }\end{array}$ \\
\hline \multirow{2}{*}{ Weight } & Female & 45 & $179.18^{\mathrm{a}}$ & 18.055 \\
& Male & 73 & $182.81^{\mathrm{a}}$ & 18.718 \\
\hline \multirow{2}{*}{$3^{\text {rd }}$ feather } & Female & 45 & $126.744^{\mathrm{a}}$ & 14.6220 \\
& Male & 73 & $126.336^{\mathrm{a}}$ & 14.3520 \\
\hline \multirow{2}{*}{ Wing length } & Female & 45 & $171.356^{\mathrm{a}}$ & 5.6434 \\
& Male & 73 & $174.473^{\mathrm{b}}$ & 5.1396 \\
\hline \multirow{2}{*}{ Tail length } & Female & 45 & $127.09^{\mathrm{a}}$ & 5.579 \\
& Male & 73 & $128.19^{\mathrm{a}}$ & 9.137 \\
\hline
\end{tabular}

Note: ${ }^{a}$ no significant difference between groups; ${ }^{\mathrm{b}}$ significant difference $(\mathrm{p}<0.05)$

The sexually active individuals were also filtered; the sex distribution of these samples was $61.3 \%$ males and $38.7 \%$ females. The sexually active individuals have the same distribution as the overall distribution (Chi-square test, $\mathrm{p}=0.922$ ) which is the sign of a stable population. Apart from male dominance in the adult age category, the population rejuvenating tendencies were shown. The overweight of males among adults can be the consequence of the early mortality of females because of the increased requisition during nesting. 
Figure 2: Tree-plot of age and sex distribution in the sampled population

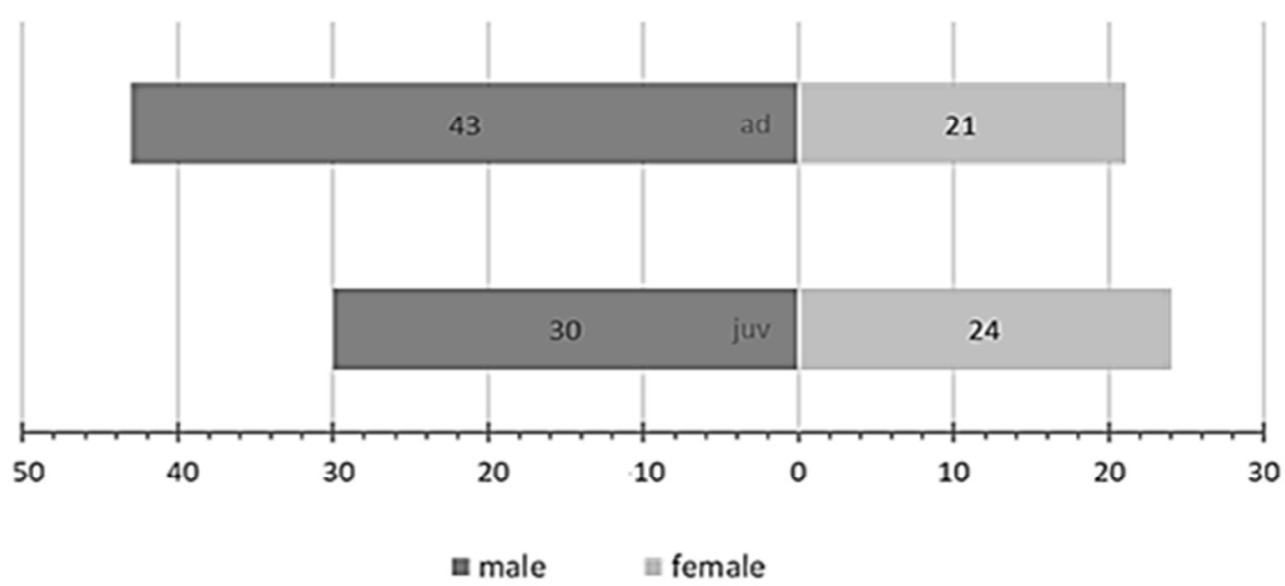

\section{DISCUSSION}

Our data was compared with former researches to see, if there is any difference in the measured indicators. This comparison revealed that there are significant differences in all cases except the tail length. Three surveys were used to ensure the correct comparison. Two of these surveys were carried out in Hungary, the third was made in Mexico, which has an added importance, because of the late expansion and the founding of this species overseas (Table 2).

Comparing means from former surveys

Table 2

\begin{tabular}{|c|c|c|c|c|}
\hline & $\begin{array}{c}\text { Measured } \\
\text { means } \\
\text { (in mixed } \\
\text { sex) }\end{array}$ & $\begin{array}{c}\text { Bozsko } \\
\text { (1983) }\end{array}$ & $\begin{array}{l}\text { Varga } \\
(2006)\end{array}$ & $\begin{array}{c}\text { Borunda } \\
\text { et al. } \\
\text { (2015) }\end{array}$ \\
\hline Weight $(\mathrm{g})$ & 181.42 & $195.93^{*}$ & $196.04 *$ & $172.93 *$ \\
\hline $3^{\text {rd }}$ quill feather $(\mathrm{mm})$ & 126.49 & m.d. & $134.30 *$ & m.d. \\
\hline Wing length (mm) & 173.28 & m.d. & $179.22 *$ & $173.62 *$ \\
\hline Tail length (mm) & 127.77 & m.d. & $129.41 *$ & $127.15^{*}$ \\
\hline
\end{tabular}

Note: $* \mathrm{p}<0.05$ significance level; m.d - missing data

Evaluation of population parameters is essential to determine the effects of corvids on nesting population. The next segment of this research is to define the same factors of a population that is highly influenced by urbanized corvid species such as Hooded Crows
(Corvus cornix) and Magpies (Pica pica). The urbanization gives an opportunity for some species to come forward, but the urban fauna has a strictly narrowed spectrum, compared to a natural habitat. (Beissinger and Osborne 1982, Rosenberg et al. 1987, Mills et al. 1989, Jokimäki and Suhonen 1993, O'Conell et al. 2000, Morelli et al. 2016, Ives et al. 2016). During urbanization granivorous, insectivorous and in air hunting insectivorous bird species are coming to view (Emlen 1974, Allen and O'Conner 2000). Permanent nesting has an advantage against wandering birds (Allen and O'Conner 2000, Kluza et al. 2000, Poague et al. 2000). The studies coping deeper with the effect of urbanization revealed that the density and diversity of birds concentrates in the peak on less disturbed, mostly suburban, or boundary zones (Jokimäki and Suhonen 1993, Blair 1999). As the urbanization effect grows, the less adaptive birds are taken out of urban ecosystem (Blair 2001). The Eurasian Collared Dove follows urban habitats and strongly connected to human presence, so the urbanizing predators are assumed as a high risk for this species.

\section{ACKNOWLEDGEMENTS}

The publication is supported by the EFOP-3.6.3VEKOP-16-2017-00008 project. The project is cofinanced by the European Union and the European Social Fund.

\section{REFERENCES}

Allen, A. P.-O'Conner, R. J. (2000): Hierarchical correlates of bird assemblage structure on Northeastern USA lakes. Environmental Monitoring Assessment. 62: 15-35.

Bankovics A. (1984): Újabb adat a Balkáni gerle (Streptopelia decaocto) hazai megjelenéséhez. Aquila. 91: 198.

Bendjoudi, D.-Voisin, J. F.-Doumandji, S.-Merabet, A.Benyounes, N.-Chenchouni, H. (2015): Rapid increase in numbers and change of land-use in two expanding Columbidae species (Columba palumbus and Streptopelia decaocto) in Algeria. Avian Research. 6: 18-26.
Blair, R. B. (1999): Birds and butterflies along an urban gradient: surrogate taxa for assessing biodiversity? Ecol. Appl. 9: 164170.

Blair, R. B. (2001): Birds and butterflies along urban gradients in two ecoregions of the United States: is urbanization creating a homogeneous fauna? [In: Lockwood and McKinney (eds.) Biotic Homogenization: The Loss of Diversity Through Invasion and Extinction.] Kluwer Academic Publishers. Boston. MA. 33-56. 
Bozsko Sz. I. (1976): A balkáni gerle (Streptopelia decaocto Friv.) expanziója a Szovjetunió területén. Állattani Közlemények. 63: 61-65.

Bozsko, Sz. (1983): The sex and age distribution as well as the major anato-morphological characteristics of the population of Collared Doves (Streptopelia decaocto Friv.) Aquila. 90: 95104.

Cramp, S. (1985): The Birds of the western Palearctic. 4. Oxford University Press. Oxford.

Emlen, J. T. (1974): An urban bird community in Tucson, Arizona: derivation, structure, regulation. Condor. 76: 184-197.

Eraud, C.-Jacquet, A.-Legagneux, P. (2011): Post-Fledging Movements, Home Range, and Survival of Juvenile Eurasian Collared-Doves in Western France. The Condor. 113. 1: 150158.

Faragó S. (szerk.) (2007): Vadászati állattan. Mezőgazdasági Kiadó. Budapest. 244-251.

Glutz von Blotzheim, U. N.-Bauer, K. M. (1980): Handbuch der Vögel Mitteleuropas. Band 9. Columbiformes - Piciformes. Akademische Verlagsgesellschaft. Wiesbaden.

Glück, E. (1987): Benefits and Costs of Social Foraging and Optimal Flock Size in Goldfinches (Carduelis carduelis). Ethology. 74: 65-79.

Greshik J. (1933): A balkáni kacagógerle Streptopelia decaocto decaocto (Friv.) Berettyóújfaluban. Kócsag. 1-2: 54-56.

Hagemeijer, W. J. M.-Blair, M. J. (1997): The EBCC Atlas of European Breeding Birds: Their distribution and abundance. T and D Poyser. London.

Ives, C. D.-Lentini, P. E.-Threlfall, C. G.-Ikin, K.-Shanahan, D. F.-Garrard, G. E.-Bekessy, S. A.-Fuller, R. A.-Mumaw, L.Rayner, L.-Rowe, R.-Valentine, L. E.-Kendal, D. (2016): Cities are hotspots for threatened species. Global Ecology and Biogeography. 25: 117-126.

Jokimäki, J.-Suhonen, J. (1993): Effects of urbanization on the breeding bird species richness in Finland: a biogeographical comparison. Ornis Fenn. 70: 71-77.

Juhász L. (1987): Egyes termény és takarmánykárosító madárfajok (balkáni gerle, házi és mezei veréb) állományának vizsgálata urbán és szuburbán ökoszisztémákban. Debreceni Agrártudományi Egyetem Tudományos Közleményei. 27: 205217.
Juhász L. (1990): A balkáni gerle állományának változása 19801990 között hazánk néhány mezőgazdasági régiójában. Debreceni Agrártudományi Egyetem Tudományos Közleményei. 30: 153-169.

Keve, A. (1950): Further notes on the range-increasing and ecology of the indian ring-dove. Aquila. 51-54: 116-122.

Keve, A. (1962): The Collared Turtle-Dove in Hungary. Aquila. 67-68: 71-78.

Keve, A.-Kleiner, A. (1944): Die Ausbreitung der orientalischen Lachtaube in Ungarn im letzten Dezennium. Aquila. 50: 264298.

Kluza, D. A.-Griffin, C. R.-DeGraaf, R. M. (2000): Housing developments in rural New England: effects on forest birds. Animal Conservation. 3. 1: 15-26.

Kövér, L.-Gyüre, P.-Balogh, P.-Huettmann, F- Lengyel, Sz.Juhász, L. (2015): Recent colonization and nest site selection of the Hooded Crow (Corvus corone cornix L.) in an urban environment. Landscape and Urban Planning. 133: 78-86.

Magyar, G.-Hadarics, T.-Waliczky, Z.-Schmidt, A.-Bankovics, A. (1998): Nomenclator Avium Hungariae. MME-Winter Fair. Budapest-Szeged. 202.

Mills, G. S.-Dunning Jr., J. B.-Bates, J. M. (1989): Effects of urbanization on breeding bird community structure in southwestern desert habitats. Condor. 91: 416-428.

Morelli, F.-Benedetti, Y.-Ibanez-Alamo, J. D.-Jokimäki, J.-Mänd, R.-Tryjanowski, P.-Møller, A. P. (2016): Evidence of evolutionary homogenization of bird communities in urban environments across Europe. Global Ecology and Biogeography. 25: 1-10.

O'Connell, T. J.-Jackson, L. E.-Brooks, R. P. (2000): Bird guilds as indicators of ecological condition in the central Appalachians. Ecol. Appl. 10: 1706-1721.

Poague, K. L.-Johnson, R. J.-Young, L. J. (2000): Bird use of rural and urban converted railroad rights-of-way in southeast Nebraska. Wildlife. Social. Biology. 28: 852-864.

Rosenberg, K. V.-Terrill, S. B.-Rosenberg, G. H. (1987): Value of suburban habitats to desert riparian birds. Wilson Bull. 99: $642-654$. 